А.В. Федоров, Д.В. Головняк, В.А. Андрієвський, С.І. Куцмус, Ю.Ю. Галаговець

Харківський національний університет Повітряних Сил імені Івана Кожедуба, Харків

\title{
АНАЛІЗ ЕФЕКТИВНОСТІ ВИКОРИСТАННЯ СИСТЕМИ МLАТ В АЕРОПОРТАХ ДЛЯ КОНТРОЛЮ ПОВІТРЯНОГО ПРОСТОРУ
}

Проведений аналіз досвіду використання системи MLAT в аеропортах світу та сучасних тендениій розвитку радіолокаційних засобів, що використовуються в системі контролю повітряного простору. Ефективність використання технологї̈ MLAT проведено на прикладі системи встановленої в аеропорту Жуляни (м. Київ). Дослідження можливостей системи здійснено за допомогою моделювання роботи реальної MLAT-системи при визначенні точності координат повітряних об'єктів в зоні відповідальності аеропорту при роботі системи в пасивному режимі, без використання функиії вимірювання дальності цілі, активному режимі та при відмові одного з приймачів. Визначені існуючі проблеми контролю повітряного простору в аеропортах та запропоновані варіанти їх вирімення.

Ключові слова: радіолокаиійна станиія, MLAT, джерела інформації, повітряна обстановка, залежсне спостереження, незалежне спостереження, контроль повітряного простору, координати.

\section{Вступ}

Постановка проблеми у загальному вигляді. Удосконалення системи спостереження за повітряним рухом передбачає не як поліпшення характеристик традиційних засобів спостереження - первинних і вторинних радіолокаторів, так і впровадження нових систем спостереження. Прикладом таких нових систем $€$ мультилатераційні системи, що знаходять все більше застосування, особливо для спостереження в термінальній зоні і на аеродромах.

Зростання повітряного трафіку та кількості пасажирських перевезень останнім часом становить світову тенденцію розвитку авіації $[1,2]$. Як наслідок, протягом наступного десятиліття інтенсивність повітряного руху в зоні відповідальності аеропортів може збільшитись майже вдвічі [2]. Сьогодні багато авіакомпаній стикаються з затримками під час перельотів через перевантаженість аеропортів і неможливість забезпечити службами контролю повітряного простору безпеки польотів. Таким чином виникає ситуація, коли засоби радіолокації не здатні контролювати повітряний рух у зв'язку зі зростаючим темпом розвитку авіаперевезень [1-4].

3 метою підвищення ефективності управління повітряним рухом за умови мінімізації витрат на інфраструктуру на сучасному етапі розвитку спостерігається перехід від традиційних радарів до систем із використанням нових технологій: MLAT та ADS-B. Системи MLAT забезпечують контроль повітряної обстановки в аеропортах в режимі реального часу, здійснюють обмін інформацією відстежують повітряні об'єкти, які знаходяться в зоні відповідальності аеропорту та забезпечують якісне спільне прийняття рішень для поліпшення управління повітряним рухом [5-6]. Суттєва перевага системи MLAT - це можливість використання сигналів пе- редавачів з борту повітряних суден, тому вони можуть розгортатися без будь-яких змін бортової інфраструктури [7]. Система MLAT не тільки гарантуе високу точність визначення місця розташування i траєкторії, але і представляє такі нові характеристики, як більш висока точність, швидкість оновлення і 3D спостереження за повітряними суднами. Для обробки сигналів на землі потрібні приймальні станції i центральний пункт обробки інформації. Системи мультилатерації успішно використовуються для спостереження в аеропортах.

Аналіз останніх досягнень і публікацій. Відомими напрямком рішення проблеми контролю повітряного руху в умовах завад, що викликані складною місцевістю, $є$ встановлення одного або кількох вторинних радіолокаторів в аеропорту або поблизу нього [8]. Але використання вторинних радіолокаторів може призвести до значних економічних витрат [8]. При цьому встановлення, технічне обслуговування та використання системи MLAT не тільки буде дешевше, але і забезпечить оптимальне покриття терміналу, більшу точність отримання необхідних даних та підвищить швидкість проведення операцій під час контролю повітряного руху.

Авіакомпанія Airservices Австралія для контролю повітряного руху над островом Тасманією, рельєф якого коливається від рівня моря до гірської місцевості, впроваджує встановлення обладнання з використанням технології MLAT. Економічні підрахунки показали, що для забезпечення надійного та ефективного контролю повітряного простору з урахуванням ландшафту потреба в коштах становить близько 3 мільйонів доларів, у тому числі обладнання, придбання землі, монтаж та обслуговування. При цьому таке ж покриття може бути отримано за допомогою 19 раціонально розміщених блоків системи MLAT. Загальна вартість обладнання з викори- 
станням MLAT виявилася значно меншою ніж при використання традиційних радіолокаційних станцій (РЛС) [7, 8].

Мета статті - провести аналіз можливості використання системи MLAT для збільшення ефективності управління повітряним рухом.

\section{Постановка задачі та викладення матеріалів дослідження}

Системи мультилатерації вже протягом тривалого часу успішно використовуються для спостереження в аеропортах. В даний час деякі системи застосовуються в більш великих районах, наприклад районах польотів за маршрутами або зонах підходу, i вони називаються системами WAM. Ця система MLAT являє собою багатопозиційну пасивну (або пасивно-активну) РЛС, що складається 3 декількох приймальних станцій, станції обробки та контрольного відповідача. Мультилатерація або гіперболічне позиціонування - процес визначення положення, заснований на різниці в часі прибуття (Time Difference of Arrival (TDOA)) сигналу, випромінюваного об'єктом у напрямку трьох або більше приймачів $[1,9]$.

Важливою особливістю роботи даної MLATсистеми є можливість використання так званого режиму «додаткового» вимірювання дальності (MultiRanging / Range-Aided techniques), коли одна зі станцій з функцією приймача працює в активному режимі [10]. Ця станція фіксує час відправлення запиту і час отримання відповіді, що дає додаткову інформацію про відстань до цілі (аналогічно визначенню відстані до цілі у вторинного оглядового радіолокатора (ВОРЛ). Природно припустити, що точність такого визначення дальності відповідає рівню сучасних ВОРЛ, а саме близько 15 м. Для моделювання точних характеристик необхідно вказати спосіб формування пар MLAT-станцій. Якщо цей спосіб невідомий, то при великій кількості станцій проводити розрахунки дуже складно.

Хоча кількість станцій в загальній системі дорівнює 18 і всі вони можуть брати участь в роботі по цілі в районі Жулян, предметом досліджень в даній роботі $є$ тільки 4 станції, розташовані в аеропорту Жуляни. Це відповідає умовній ситуації, коли бортовий сигнал впевнено реєструється тільки цими 4ма станціями.

Відзначимо, що в загальних вимогах на систему задавалася тільки середньоквадратична похибка визначення горизонтального положення, яка в зоні аеропорту Жуляни не повинна перевищувати 25 м. Так як кількість станцій MLAT-системи дорівнює 4, можливо вимір і висоти польоту, але при відмові будь-який 3 цих станцій ця функція втрачається. Для визначення ж горизонтального положення $є$ навіть одна надлишкова станція, що підвищує надійність роботи даної системи.

Розташування станцій MLAT-системи в аеропорту Жуляни показано на рис. 1.

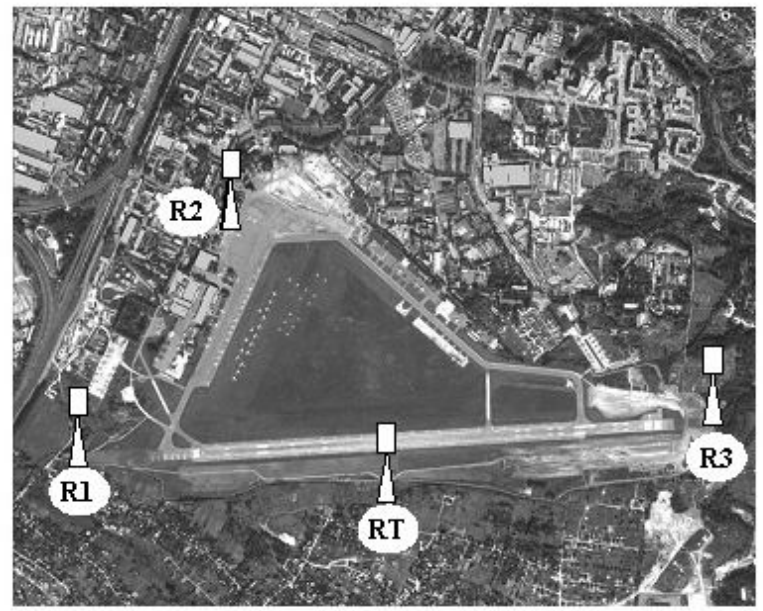

Рис. 1. Розміщення системи MLAT в аеропорту Жуляни. RT-прийомоперадавач R1,R2,R3-приймачі

Приймальні станції R1 i R2 розташовані на протилежних кінцях злітно-посадкової смуги (ЗПС) аеропорту. Третій приймач розташований в районі північної вершини території аеропорту, а прийомопередавач південніше всередині злітно-посадкової смуги (ЗПС). Розрахунки ряду конфігурацій системи, наведені у табл. 1.

Таблиця 1

Розрахунки ряду конфігурацій системи

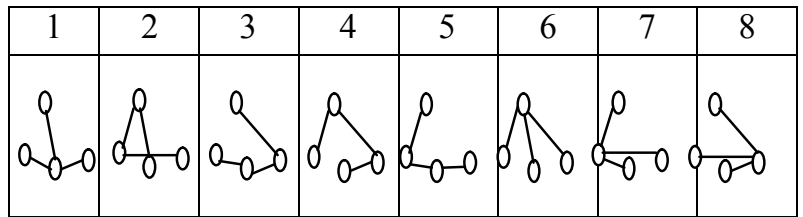

Лініями з'єднані відповідні пари станцій. Можливі комбінації пар цим, зрозуміло, не вичерпуються, але дають уявлення про різноманітність варіантів.

На рис. 2 показані контури точності, відповідні горизонтальному середньо-квадратичному відхиленню $($ СКВ $)=25$ м. Контуром точності називається замкнута крива, в межах якої похибка не перевищує заданого значення (в даному випадку 25 м).

Всі подальші дослідження проведені для конфігурації «1» 3 табл. 1 .

Розглянемо, яка точність виходить на кордонах аеропорту Жуляни при роботі системи в пасивному режимі, без використання функції вимірювання дальності цілі.

Результати розрахунків контурів точності показані на рис. 2, а.

Зі збільшенням відстані від системи похибка швидко збільшується, досягаючи значень 500 м і більше. Згідно з розрахунками, в зоні підходу аеро- 
порту Жуляни повністю поміщається в контур точності,відповідний середньоквадратичному відхиленню (СКВ), що дорівнює 2000 м. Це означає, що при роботі в пасивному режимі 3 чотирма станціями домогтися, щоб геометрична складова похибки не перевищувала 25 м можна тільки при точності синхронізації більше 0,04 нс. Така точність синхронізації роботи стацій навряд чи досяжна.

Але система має інший, ефективний спосіб підвищення точності визначення місця розташування повітряного об'єкта. Це активний режим роботи, коли приймач визначає відстань до цілі аналогічно тому, як це робить ВОРЛ.

Результати розрахунку контурів точності при активному режимі роботи MLAT-системи 3 чотирьох станцій показані на рис. 2, б. Видно, що у всьому районі підльоту аеропорту Жуляни похибка не перевищує значення СКВ $=20$ м, тобто вимоги до системи виконуються з запасом.

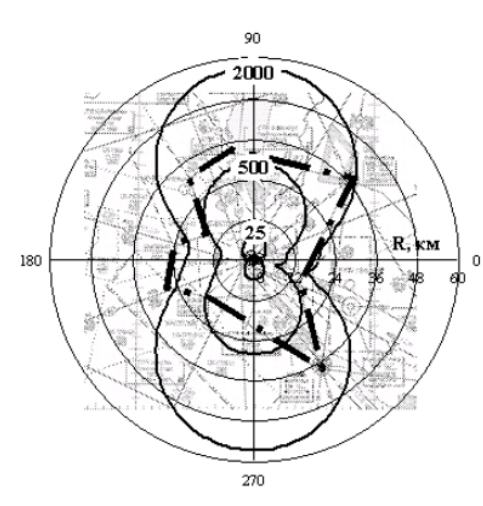

a

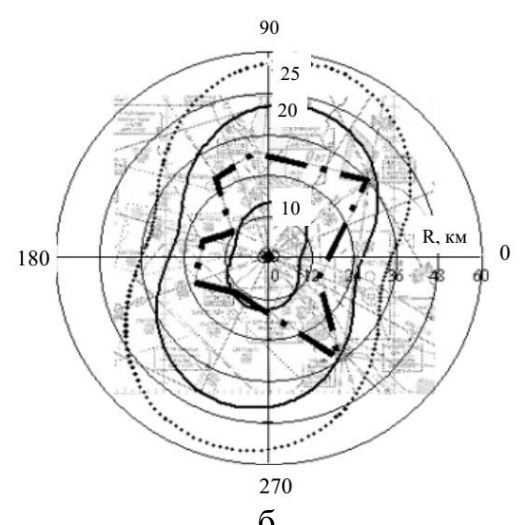

6

Рис. 2. Контури точності в районі підльоту аеропорта Жуляни (штрихпунтирна лінія) при роботі MLAT в пасивному (а) та активному (б) режимах

Як вже зазначалося вище, навіть система всього $з$ чотирьох станцій має одну надлишкову станцію при визначенні положення повітряного об'єкта в горизонтальній площині. Результати моделювання відмови однієї з трьох прийомних станцій представлені на рис. 3.

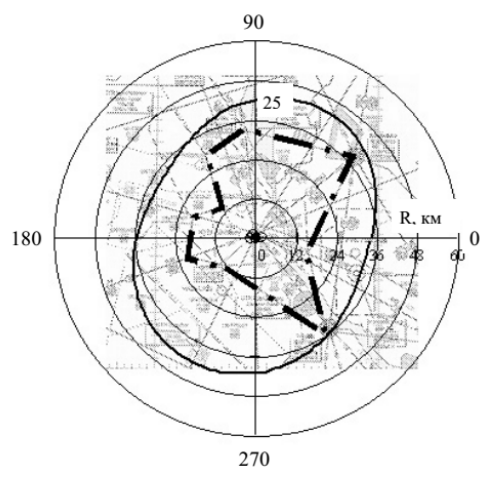

a

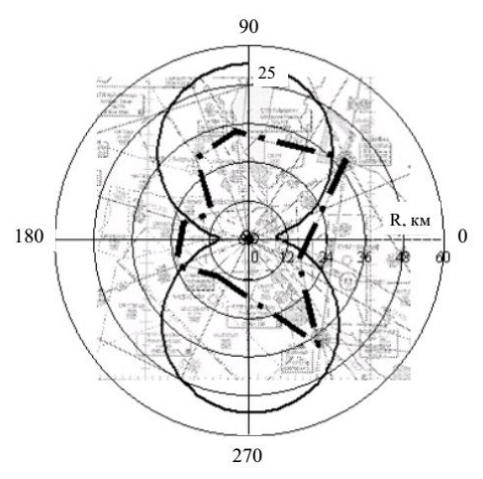

6

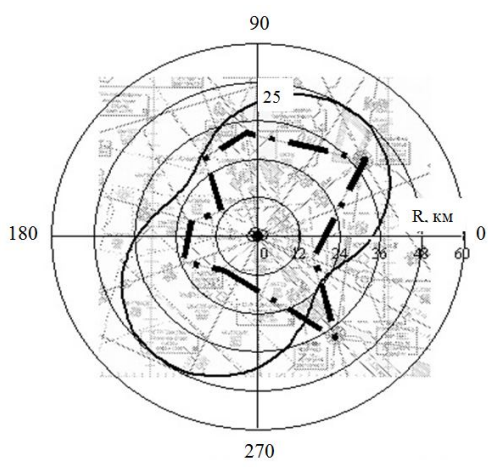

B

Рис. 4. Контури точності в районі аеропорта Жуляни (штрихпунтирна лінія) при роботі MLAT в активному режимі при відмові станції R1 (a), R2 (б), R3 (в)

Видно, що контури точності помітно відрізняються. найменший вплив надає відмову приймача R1 (рис. 5). При цьому вся зона підходу лежить в межах контуру точності, відповідного СКВ $=25$ м.

При відмові приймача R3 поза контуром виявляється незначна площа в одному з напрямків підходу (рис. 6), тобто вимоги до точно не задовольняються, але відхилення невелике. В цьому випадку можна вважати, що система практично зберігає свою працездатність. Здавалося б, що найгірша ситуація при відмові приймальної станції R2 (рис. 5). Але, якщо подивитися уважніше, то виявляється, що в тих напрямках, де контур точності не перекриває зону підходу, не показані маршрути підходу до аеропорту. Тому ризик помилитися менше, і можна говорити про практичну працездатність.

Системи MLAT можна розділити на активні і пасивні. Пасивна система включає тільки приймачі, а активна система має одну або кілька передаваль- них антен для запиту бортового прийомовідповідача ВОРЛ. Основна перевага активної системи полягає у тому, що вона не залежить від інших джерел ініціювання передачі даних з борту повітряного судна. Головний іiі недолік пов'язаний з тим, що вона створює додаткові перешкоди на каналах 1030 МГц і 1090 МГц [11, 12].

\section{Висновки і напрямки подальших досліджень}

В роботі основна увага приділена системі незалежного кооперативного спостереження MLAT. Проведено детальний аналіз ефективності використання даної системи встановленої в аеропорту Жуляни (м. Київ). Таким чином можна зробити такі висновки:

1. Для забезпечення заданої точності необхідне використання активного режиму роботи системи, тобто додаткового визначення дальності. 
2. Система є стійкою до відмов. При відмові приймача R1 забезпечується повна працездатність, а при відмовах R2 i R3 порушення працездатності незначне.

Автоматичне залежне спостереження в режимі радіомовлення (ADS-B) буде одним 3 ключових елементів майбутньої системи організації повітряного руху, так як в Європі програми SESAR i NextGen у США. Однак, широке впровадження слід очікувати не раніше чим у 2020-2025 роках.

Однією з головних причин того, що використання даних систем не буде повністю реалізовано протягом багатьох років є дорога вартість обладнання повітряних суден усім необхідним авіаційним обладнанням для передачі і прийому ADS-B інформації. Крім того, повільний перехідний період ускладняється тим, що ADS-B і РЛС використовують дуже різні технології.

\section{Список літератури}

1. Мультилатераційні системи спостереження повітряного руху. Навчальний посібник. Під загальною редакиією Яковлєва О.І. - К.: ДПОПР Украӥни, 2010-192 с.

2. Зайцев, Д.В. Многопозиционные радиолокачионные системы / Д.В. Зайцев. - М.: Радиотехника, 2007. $114 \mathrm{c}$.

3. Fewell M. P. Area of common overlap of three circles / M. P. Fewell// Maritime operations divisions defences science and technology organization. - 2006. - P. 1-30.

4. Li J. MIMO Radar Signal Processing / Edited by Jian Li and Petre Stoica - New Jersey : John Wiley \& Sons Inc., 2009. - $448 p$.

5. Лещенко С.П., Колеснік О.М., Бейліс Л.В., Грицаєнко С.А. Шляхи створення єдиної картини повітряної обстановки для виявлення загрозливих і кризових ситуацій в повітрі. Новітні технології - для захисту повітряного простору: Тези допов. 13 наук. конф. Харк. нац. ун-ту Повітряних Сил ім. Івана Кожедуба (Харків 12-13 квіт. 2017). Х.: ХНУПС, 2017. С. 204.

6. Surveillance Transition Scenario for German Airspace. Results of the DFS ADS-B Study Group. DFS Deutsche Flugsicherung GmbH. Heribert Lafferton, Dr. Roland Mallwitz. January 31, 2007.

7. WAM Safety Study \& Surveillance Generic Safety. Eurocontrol. Bob Darby. November 9, 2007.

8. Гониа Д.І. Використання складних широкосмугових сигналів у системі мультиратераиії MLAT [Електронний ресурс] / ДонНТУ. - Режим доступу: URL: http://masters.donntu.org/2014/frt/gontsa/diss/indexu.htm 10.10.2017.

9.Свид I.В. Синтез структури інформачійного забезпечення споживачів інформачійними системами спостереження повітряного простору / I.В. Свид, А.І. Обод// Збірник наукових праџьь ХУПС. - Х.: ХУПС, 2015. Bun. 2 (43). - C. 67-70.

10. Обод I.I. Інформаційна модель систем спостереження повітряного простору / I.I. Обод, О.О. Стрельницький, В.А. Андрусевич. - Х.: ХНУРЕ, 2015. - 270 с.

11. Multilateration: Radar's Replacement? Avionics. Callan James. April, 2007. Pages 30-34.

12."RTCA DO-260B. Minimum Operational Performance Standards for $1090 \mathrm{MHz}$ Extended Squitter Automatic Dependent Surveillance - Broadcast (ADS-B) and Traffic Information Services - Broadcast (TIS-B)" // [Standards] / RTCA, Inc - [Washington, 2009].

Надійшла до редколегії 12.02.2018

Рецензент: д-р техн. наук, проф. К.С. Васюта, Харківський національний університет Повітряних Сил імені Івана Кожедуба, Харків.

\section{АНАЛИЗ ЭФФЕКТИВНОСТИ ИСПОЛЬЗОВАНИЯ СИСТЕМЫ МLАТ В АЭРОПОРТАХ ДЛЯ КОНТРОЛЯ ВОЗДУШНОГО ПРОСТРАНСТВА}

А.В. Федоров, Д.В. Головняк, В.А. Андриевский, С.І. Куцмцс, Ю.Ю. Галаговец

Проведен анализ опыта использования системы MLAT в аэропортах мира и современных тенденций развития радиолокачионных средств, используемых в системе контроля воздушного пространства. Эффективность использования технологии MLAT проведения на примере системы установленной в аэропорту Жуляны (2.Киев). Исследование возможностей системы осуществлено с помощью моделирования работы реальной MLAT-системы при определении точности координат воздушных объектов в зоне ответственности аэропорта при работе системы в пассивном режиме, без использования функиии измерения дальности цели, активном режсиме и при отказе одного из приемников. Определень существующие проблемы контроля воздушного пространства в аэропортах и предложены варианты их решения.

Ключевые слова: радиолокационная станция, MLAT, источник информации, воздушная обстановка, зависимое наблюдение, независимое наблюдение, воздушное пространство, контроль воздушного пространства, координаты.

\section{ANALYSIS OF THE EFFICIENCY OF THE USE OF MLAT SYSTEM IN AIRPORTS FOR AIR SPACE CONTROL}

A.V. Fedorov, D.V. Golovnyak, V.A. Andrievskii, S.I. Kutsmus, Yu. Yu. Galagovets

The article analyzes the use of the MLAT system at the airports of the world, its essence and direct role in airspace control. The analysis of existing trends in the development of radar equipment in the airspace control system is carried out. As an example, a detailed analysis of the efficiency of the use of this system installed at the airport Zhulyany (Kiev) was conducted. One of the examples of simulation of the real MLAT system in determining the accuracy of airspace coordinates in the zone of responsibility of the Zhulyany airport is when the system operates in a passive mode, without using the target range measurement function, active mode and refusal of one of the receivers. The analysis is limited to using only 4 stations. An analysis of existing airspace control problems at airports around the world was carried out and variants of their solutions were considered using the MLAT system. The modeling of MLAT system, implemented in CTR Zhuliany-Boryspil, was completed. Although system also includes many stations at Boryspil airport, only 4 stations, allocated directly in Zhuliany, were investigated. High reliability of this system with using so-called Multi-Ranging/Range-Aided techniques was demonstrated.

Keywords: radars, control point, information source, air situation, dependent observation, independent observation, airspace, airspace control, coordinates. 